\title{
Frequency of 'Chronic Active Epstein-Barr Virus Infection' in a General Medical Practice
}

\section{Citation}

Buchwald, Dedra, John L. Sullivan, Anthony L. Komaroff. 1987. Frequency of 'Chronic Active Epstein-Barr Virus Infection' in a General Medical Practice. JAMA 257, no. 17:2303-2307.

\section{Permanent link}

http://nrs.harvard.edu/urn-3:HUL.InstRepos:42656647

\section{Terms of Use}

This article was downloaded from Harvard University's DASH repository, and is made available under the terms and conditions applicable to Other Posted Material, as set forth at http:// nrs.harvard.edu/urn-3:HUL.InstRepos:dash.current.terms-of-use\#LAA

\section{Share Your Story}

The Harvard community has made this article openly available.

Please share how this access benefits you. Submit a story.

\section{Accessibility}




\title{
Frequency of 'Chronic Active Epstein-Barr Virus Infection' in a General Medical Practice
}

\author{
Dedra Buchwald, MD; John L. Sullivan, MD; Anthony L. Komaroff, MD
}

Twenty-one percent of 500 unselected patients, aged 17 to 50 years, seeking primary care for any reason were found to be suffering from a chronic fatigue syndrome consistent with "chronic active Epstein-Barr virus (EBV) infection." They had been experiencing "severe" fatigue, usually cyclic, for a median of 16 months (range, six to 458 months), associated with sore throat, myalgias, or headaches; $45 \%$ of the patients were periodically bedridden; and $25 \%$ to $73 \%$ reported recurrent cervical adenopathy, paresthesias, arthralgias, and difficulty in concentrating or sleeping. The patients had no recognized chronic "physical" illness and were not receiving psychiatric care. While antibody titers to several EBV-specific antigens were higher in patients than in age- and sex-matched control subjects, the differences generally were not statistically significant. A chronic fatigue syndrome consistent with the chronic active EBV infection syndrome was prevalent in our primary care practice. However, our data offer no evidence that EBV is causally related to the syndrome. Indeed, we feel that among unselected patients seen in a general medical practice currently available EBV serologic test results must be interpreted with great caution.

(JAMA 1987;257:2303-2307)

MOST human beings have been infected with the Epstein-Barr virus (EBV). The clinical manifestations of initial infection are variable; some patients are asymptomatic, others develop mild respiratory infection symptoms, and others develop the clinical, serologic, and hematologic features of infectious mononucleosis. ${ }^{1-3}$ When there are symptoms associated with the initial infection, these usually resolve within a mat-

From the Division of General Medicine and Primary Care, Department of Medicine, Brigham and Women's Hospital and Harvard Medical School, Boston (Drs Buchwald and Komaroff); and the Department of Pediatrics, Molecular Genetics, and Microbiology, University of Massachusetts, Worcester (Dr Sullivan).

Reprint requests to Division of General Medicine and Primary Care, Brigham and Women's Hospital, 75 Francis St, Boston, MA 02115 (Dr Komaroff). ter of weeks. However, the virus can be isolated from saliva for months or years thereafter, suggesting chronic infection of the nasopharyngeal epithelium and/ or salivary glands. ${ }^{4}$ Also, a small fraction of B lymphocytes remain latently infected, apparently for the rest of the patient's life. $^{5}$

\section{See also pp 2297 and 2335.}

On occasion, individuals with various forms of immunodeficiency will be unable to contain the population of EBVinfected B cells, and they will go on to develop polyclonal B-cell proliferation and monoclonal B-cell lymphomas. . $^{6-16}$

Several investigators have reported another kind of chronic illness associated with, and perhaps secondary to, persistent EBV infection. The syndrome is called chronic active $E B V$ (CEBV) infection or chronic mononucleosis, and it is characterized by varying degrees of chronic fatigue, fever, pharyngitis, myalgias, headache, arthralgias, paresthesias, depression, and cognitive deficits. While the full syndrome has been described only in recent years, ${ }^{17-23}$ earlier reports that may have been reporting the same phenomenon exist in the literature. ${ }^{24-36}$ The onset of the syndrome typically seems to be in late adolescence or young adulthood, ${ }^{17-23}$ although it may also occur in childhood. ${ }^{22}$ By definition, patients with this syndrome have been evaluated for a variety of chronic infectious, rheumatologic, endocrinologic, and malignant diseases, and no chronic disease is apparent. ${ }^{17,21-23}$ The diagnosis has been made about twice as often in women as in men. ${ }^{17,20-23}$ The illness may follow a documented episode of infectious mononucleosis, or an acute viral syndrome for which the patient has not sought medical attention, but also may appear spontaneously. ${ }^{17,21-23}$ For most patients, the illness takes the form of a chronic, recurring "flulike" illness. ${ }^{21-23}$ Virtually all patients perceive themselves to be impaired in some way. Some patients are completely disabled by the fatigue, muscular weakness, and pain.

The results of laboratory tests generally ordered in patients with chronic fatigue are typically unremarkable. However, three recent reports all state that patients with this chronic fatigue syndrome have significant elevation of IgG antibody to the EBV viral capsid 
antigen (VCA) and to EBV early antigens (EA-Ab), in contrast with "healthy" patients. ${ }^{21-23}$ Also, one of these reports has suggested the possibility that levels of antibodies to EB nuclear antigen (EBNA-Ab) are low in a subset of patients. ${ }^{22}$ Case reports also have described patients with extraordinarily high titers of VCA-IgG and EA-Ab. . $^{19,37-39}$

The high titers to VCA and EA typical of patients with the syndrome also can be seen in an occasional healthy patient. ${ }^{40-42}$ Also, not all patients reported to have the syndrome have elevated titers. ${ }^{21-23}$

Because fatigue is a common presenting complaint in general medical practices, the general physician would like to know how common CEBV infection is among patients seen in a general practice setting. To our knowledge, previous published reports have not systematically addressed this question but have described only patients who in some way have come to the attention of the investigators. The general physician also would like to know the utility of serologic testing for EBV in a primary care practice setting; the patients reported in the literature have been highly selected and may have different clinical and serologic characteristics.

To address these two questions, we conducted a prospective study in a primary care practice setting.

\section{PATIENTS AND METHODS Study Setting and Patient Population}

The study was conducted over a sixmonth period in a large ( 30000 visits per year) primary care general medical practice located in a large academic teaching hospital (Brigham and Women's Hospital, Boston). The practice was staffed by 12 faculty members, four fellows, 85 house officers, and four nurse practitioners. Prior to and during the time of the study, the interest of the authors in the CEBV infection syndrome was not widely known, and the practice was not being asked to see patients with CEBV infection in consultation.

The practice is divided into six areas, each with its own waiting room. $\mathrm{Pa}$ tients are scheduled to each area during 9 four-hour sessions per week. During a four-month period, research assistants were assigned to interview patients in a particular waiting room, during a particular session. They were asked to interview as many patients between the ages of 17 and 50 years during each session as time would allow. The waiting rooms and sessions were rotated during the four months of the study as to be representative of the entire practice.
During each interview session, patients were asked, prior to seeing their physician, the following question: "Have you had severe loss of energy or easy fatigability either constantly or recurrently for at least the past six months?" Patients who answered affirmatively were then asked: "Since you've been tired, have you had any of the following symptoms more than once: sore throat, muscle aches, or headaches?" The patients were also asked if they were pregnant, if they were taking corticosteroids or azathioprine, or if they had any of the following chronic diseases: diabetes, chronic lung disease, cancer, heart disease, anemia, kidney disease, liver disease, thyroid disease, rheumatoid arthritis, systemic lupus erythematosus, or other autoimmune disorders. Each patient's medical record was reviewed in detail with reference to each of the above questions, and to determine whether they were under psychiatric care at the time of the onset of their chronic fatigue syndrome.

\section{Clinical and Laboratory Data Collected}

Clinical Data.-We asked the following patients to participate in the study: patients who stated that they did have a severe loss of energy for at least the past six months; and who had either recurrent sore throat, myalgias, or headaches; and who were not pregnant, nor taking immunosuppressive drugs, nor suffering from any of the above chronic diseases. Each patient gave written informed consent. A detailed questionnaire was then completed that inquired into present and past medical history. The patient's physician was asked to record the presence or absence of various physical examination findings on a study protocol.

Laboratory Data.-From each patient, a single serum specimen was obtained at the index visit. Titers of IgM and IgG antibodies to VCA (VCA-IgM and VCA-IgG), as well as IgG antibodies to the early antigens (EA-Ab), were determined by indirect immunofluorescence..$^{43}$ No attempt was made to distinguish the restricted and diffuse components of EA-Ab. The EBNA-Ab were detected by anticomplement immunofluorescence. ${ }^{44}$ Titers were reported as zero when VCA-IgG was present in a dilution of less than 1:20; when VCA-IgM was present in a dilution of less than 1:20; when EA-Ab was present in a dilution of less than 1:20; and when EBNA-Ab was present in a dilution of less than 1:5-due to unreliability of measurements at these low levels of antibody. All antibody titers were performed in a single laboratory by a single technician who routinely performs about $1000 \mathrm{EBV}$ antibody profiles per year.

Control Subjects.-From the ambulatory practices of the Brigham and Women's Hospital, a group of "control" subjects matched for age (within five years) and sex to each of the study patients was identified. Control subjects were selected from patients scheduled to have a venipuncture performed. Typically, they were attending the practice for routine screening examinations; each subject was explicitly asked about, and explicitly denied, the presence of severe, prolonged chronic fatigue. Also, through a detailed review of the medical record, each control patient was deemed to be not pregnant, free of the chronic diseases listed above, and not receiving immunosuppressive drugs. Serum specimens obtained from each subject were tested for antibodies to $\mathrm{EBV}$ as described above. The technician tested patient and control subject serum specimens simultaneously and was blinded to the patient or control status of the serum specimens.

\section{Statistical Analysis}

Calculation of Geometric Mean Titers (GMTs). - The GMTs in the patients were compared with those in the control subjects using both parametric and nonparametric methods. The comparisons were made for the entire group of patients and control subjects and for each of several patient subgroups and their matched control subjects. Using parametric methods (Student's paired $t$ test, two tailed), we first attempted to normalize the distribution; the value of each serologic result was log transformed (base 10). Patients with "zero" antibody detected were given an arbitrary value of 1 instead of 0 , so that GMTs could be determined on the entire population, not just on patients with seropositivity. We also compared antibody levels in patients and control subjects by use of the nonparametric paired Wilcoxon rank-sum test.

Percentages.-Percentages of patients with a certain serologic finding were compared with the percentage of control subjects with that finding, using the $\chi^{2}$ or Fisher's exact test (two tailed).

\section{RESULTS}

\section{Study Population}

Altogether, 500 patients were interviewed. They were representative of all patients between the ages of 17 and 50 years seen in our practice during the period of the study, as determined from a computerized patient registration and billing system: there were no significant 


\begin{tabular}{|c|c|}
\hline Findings & $\begin{array}{c}\text { No. of } \\
\text { Patients } \\
\text { (\% of Total) }\end{array}$ \\
\hline \multicolumn{2}{|l|}{ History } \\
\hline Chief complaint is the fatigue syndrome & $12(30)$ \\
\hline \multicolumn{2}{|l|}{ Severity of the fatigue at its worst } \\
\hline Bedridden: can do virtually nothing & $11(28)$ \\
\hline Shut-in: cannot do even light housework or its equivalent & 5 (13) \\
\hline $\begin{array}{l}\text { Can do all the things I usually do at home or work, but feel much more easily fatigued from it: } \\
\text { no energy left for anything else }\end{array}$ & \\
\hline \multicolumn{2}{|l|}{ Description of the frequency of the fatigue } \\
\hline Constant fatigue that does not change & $6(15)$ \\
\hline Always some fatigue that may get better but never goes away completely & $9(23)$ \\
\hline The fatigue alternates with periods of feeling normal & $25(63)$ \\
\hline Associated recurrent pharyngitis & $24(60)$ \\
\hline Associated recurrent muscle aches & $32(80)$ \\
\hline \multicolumn{2}{|l|}{ Severity of muscle aches at their worst $(N=31)$} \\
\hline Need to stop all normal activities and rest & $12(39)$ \\
\hline Can continue normal activities but muscle aches make it hard & $7(23)$ \\
\hline Not aware of muscle aches during normal activities, only at rest & $12(39)$ \\
\hline Associated recurrent headaches & 33 (83) \\
\hline \multicolumn{2}{|l|}{ Severity of headaches at their worst $(\mathrm{N}=33$ ) } \\
\hline Need to stop all normal activities and rest & $18(55)$ \\
\hline Can continue normal activities but headaches make it hard & 11 (33) \\
\hline Not aware of headaches during normal activities, only at rest & $4(12)$ \\
\hline Fatigue plus sore throat, plus myalgias, plus headaches & $18(45)$ \\
\hline \multicolumn{2}{|l|}{ Associated symptoms } \\
\hline Depression or unusual mood changes & $31(78)$ \\
\hline Difficulty in sleeping & 29 (73) \\
\hline Difficulty in concentrating & $26(65)$ \\
\hline Anxiety & $24(60)$ \\
\hline Nausea & $22(55)$ \\
\hline Swollen lymph glands $(\mathrm{N}=39)$ & 17 (44) \\
\hline Stomach ache & $16(40)$ \\
\hline Diarrhea & $15(38)$ \\
\hline Cough & $15(38)$ \\
\hline Rash & $14(35)$ \\
\hline Odd sensations in skin & 13 (33) \\
\hline Loss of appetite & $12(30)$ \\
\hline Joint pain & $12(30)$ \\
\hline Vomiting & $10(25)$ \\
\hline Recurrent fevers at home & $10(25)$ \\
\hline Intermittent swelling of fingers $(\mathrm{N}=30)$ & $6(20)$ \\
\hline Weight loss & $6(15)$ \\
\hline Weight gain & $2(5)$ \\
\hline Have seen a physician for this problem previously & $22(55)$ \\
\hline Have seen more than one physician for this problem & $10(25)$ \\
\hline The problem has caused problems or stress at home and at work & $24(60)$ \\
\hline Patient has sometimes thought these symptoms "might just all be in my head" & $23(58)$ \\
\hline \multicolumn{2}{|l|}{ Past history } \\
\hline Mononucleosis $(\mathrm{N}=39)$ & $10(26)$ \\
\hline Oral herpes & $15(38)$ \\
\hline Genital herpes & $0(0)$ \\
\hline Herpes zoster ("shingles") & $0(0)$ \\
\hline Allergies (to foods or drugs, or "hay fever") & $21(53)$ \\
\hline \multicolumn{2}{|l|}{ Physical examination } \\
\hline Tonsillar/pharyngeal exudate & $0(0)$ \\
\hline \multicolumn{2}{|l|}{ Cervical adenopathy (enlarged or tender nodes) } \\
\hline Anterior & $6(15)$ \\
\hline Posterior & $1(3)$ \\
\hline Submandibular gland, enlarged or tender $(\mathrm{N}=38)$ & $5(13)$ \\
\hline Hepatomegaly or splenomegaly & $0(0)$ \\
\hline Temperature $>37.5^{\circ} \mathrm{C}$ & $0(0)$ \\
\hline
\end{tabular}

differences between the 500-patient sample and the entire population with regard to age, sex, or medical insurance coverage.

Of these 500 patients, 185 stated that they had been experiencing severe fatigue for at least six months; of these 185 patients, 176 complained not only of fatigue but also of associated sore throat, muscle aches, or headaches. Of these 176 patients, 103 had no other known condition or illness that could explain the chronic fatigue and associated symptoms. Thus, 103 (21\%) of 500 patients aged 17 to 50 years seeking primary care in our practice complained of symptoms suggestive of CEBV infection, ie, severe fatigue for at least the past six months, with associated symptoms of sore throat, myalgias, or head- eligible patients who declined to participate: mean age (34 vs 33 years); sex ( $70 \%$ vs $75 \%$ female); and severity of illness-percentage with fatigue and sore throat and myalgias and headache ( $29 \%$ vs $45 \%$ ).

\section{Clinical Findings}

Table 1 summarizes the historical and physical examination findings. The full text of the historical questions asked of the patients is presented in Table 1 . The patients described a syndrome of considerable severity; $28 \%$ stated that the fatigue at its worst was sufficient to make them "bedridden: can do virtually nothing." Nearly half of the patients reported "swollen lymph glands," particularly in the neck. Low-grade fevers were reported by $25 \%$ of patients; 14 patients recorded their temperatures in the morning and evening for one week following the index visit, and six of the 14 reported temperatures between $37.2^{\circ} \mathrm{C}$ and $37.5^{\circ} \mathrm{C}$.

The median duration of the symptoms was as follows: fatigue, 16 months (six to 458 months); pharyngitis, 13 months ( 0.5 to 96 months); headache, 13 months ( 0.5 to 144 months); and myalgias, 17 months (one to 84 months). The patients were asked explicitly if they had suffered from these associated symptoms since the onset of the severe fatigue. A detailed history of past experience with pharyngitis, headache, and myalgias was not obtained. The patients reported an average of six sick days in the preceding six months (range, zero to 40 days per patient).

A majority of patients had seen a physician previously in an attempt to diagnose and treat the problem, and $25 \%$ had seen more than one physician. Sixty percent of the patients stated that the chronic fatigue syndrome had created substantial stress both at home and in the workplace.

Physical examination findings were benign. None of the patients had a fever at the time of examination. Fifteen percent had anterior cervical adenopathy, and $13 \%$ had enlarged submandibular glands.

\section{Serologic Findings}

The VCA-IgG was found in $39 / 40$ (98\%) of patients and $36 / 40(90 \%)$ of control subjects $(P=\mathrm{NS})$. The EA-Ab was found in $30 / 40(75 \%)$ of patients and $24 / 40(60 \%)$ of control subjects $(P=\mathrm{NS})$. The EBNA-Ab was found in $39 / 40(98 \%)$ of patients and $34 / 40(85 \%)$ of control subjects $(P=\mathrm{NS})$. The VCA-IgM was detected in $4 / 40(10 \%)$ of patients and in none of 40 control subjects $(P=N S)$. In the four patients with VCA-IgM, the values of $\mathrm{EA}-\mathrm{Ab}$ were 1:20, 1:40, 1:40, 
Table 2.-Comparisons of Serologic Results, Different Patient Groups, and Their Matched Control Subjects*

\begin{tabular}{|c|c|c|c|c|c|c|}
\hline & \multicolumn{6}{|c|}{ GMTs \pm SD } \\
\hline & \multicolumn{2}{|c|}{ VCA-IgG } & \multicolumn{2}{|c|}{ EA-Ab } & \multicolumn{2}{|c|}{ EBNA-Ab } \\
\hline & Patlents & Controls & Patients & Controls & Patients & Controls \\
\hline All patients $(\mathrm{N}=40)$ & $134.9 \pm 3$ & $81.2 \pm 5$ & $18.2 \pm 6$ & $10.0 \pm 7$ & $13.2 \pm 2$ & $8.5 \pm 3$ \\
\hline $\begin{array}{l}\text { Patients with chief complaint } \\
\text { of chronic fatigue }(n=12)\end{array}$ & $151.3 \pm 2$ & $38.0 \pm 10$ & $11.8 \pm 7$ & $12.3 \pm 10$ & $12.9 \pm 2$ & $6.0 \pm 3$ \\
\hline $\begin{array}{l}\text { Patients with fatigue plus } \\
\text { sore throat plus headaches } \\
\text { plus myalgias }(n=18)\end{array}$ & $117.5 \pm 2$ & $52.5 \pm 8$ & $13.8 \pm 6$ & $6.0 \pm 8$ & $10.7 \pm 2$ & $6.8 \pm 4$ \\
\hline $\begin{array}{l}\text { Patients with most severe } \\
\text { fatigue (intermittently } \\
\text { bedridden/homebound) }(n=16)\end{array}$ & $147.9 \pm 2$ & $102.3 \pm 5$ & $16.2 \pm 6$ & $15.9 \pm 7$ & $11.5 \pm 2$ & $9.6 \pm 3$ \\
\hline $\begin{array}{l}\text { Patients with cervical } \\
\text { adenopathy or enlarged } \\
\text { submandibular glands }(n=12)\end{array}$ & $123.0 \pm 2$ & $50.1 \pm 9$ & $28.2 \pm 3$ & $10.5 \pm 8$ & $10.5 \pm 2$ & $7.4 \pm 4$ \\
\hline $\begin{array}{l}\text { Patients with history of } \\
\text { mononucleosis }(n=10)\end{array}$ & $162.2 \pm 2 \dagger$ & $93.3 \pm 1 \dagger$ & $16.2 \pm 7$ & $6.3 \pm 7$ & $15.1 \pm 2$ & $8.1 \pm 2$ \\
\hline
\end{tabular}

and $1: 160$, respectively; the values of EBNA-Ab were $1: 5,1: 10,1: 40$, and 1:10, respectively.

The VCA-IgG levels were 1:320 or greater in $12 / 40(30 \%)$ of patients and $8 / 40(20 \%)$ of control subjects $(P=\mathrm{NS})$; $\mathrm{EA}-\mathrm{Ab}$ levels were 1:40 or greater in $22 / 40(55 \%)$ of patients and $17 / 40(43 \%)$ of control subjects $(P=\mathrm{NS})$; these levels had been regarded as "abnormal" in our laboratory. In the patient group, 11/40 (28\%) of patients and $6 / 40$ (15\%) of control subjects $(P=\mathrm{NS})$ had both VCA-IgG levels of 1:320 or greater and $\mathrm{EA}-\mathrm{Ab}$ levels of $1: 40$ or greater.

Table 2 displays the GMTs of VCAIgG, EA-Ab, and EBNA-Ab in all patients and all matched control subjects, and in specific patient subsets (with their matched control subjects). In all but one of the 43 comparisons reported in the above paragraphs and in Table 2, the EBV antibody levels in patients were higher than in the matched control subjects. However, in only one instance was the difference between patients and control subjects statistically significant $(P=.015)$ (the subset of patients with a history of mononucleosis). Given the relatively small cell sizes in the various paired comparisons, the power of the study to recognize real numerical differences of the magnitude shown in Table 2 was weak, ranging from $3 \%$ to $69 \%$ and averaging $28 \%$. The only comparison in which the power was greater than 50\%-VCA-IgG levels in patients with a history of mononucleosis, compared with their age- and sex-matched controls-was the only instance in which a significant difference was found.

\section{COMMENT}

Chronic active EBV infection is a controversial clinical entity. There seems to be little doubt that some pa- tients with extraordinarily high titers of EBV antibodies (particularly VCA-IgG and $\mathrm{EA}-\mathrm{Ab}$ ) really are suffering from a syndrome associated with reactivation of EBV. ${ }^{19,37-39}$

Several recent reports have described patients with less dramatic elevations of EBV antibody titers. ${ }^{21-23}$ These reports involved highly selected patients who were referred to investigators known to have an interest in CEBV infection. No attempt was made by these investigators to ascertain the prevalence of the condition. Levels of EBV antibodies (VCA-IgG and EA-Ab) were significantly higher in these patients than in control subjects, suggesting that measurement of antibodies to EBV has diagnostic value in highly selected patients.

These recent reports ${ }^{21-23}$ provide further evidence of a chronic fatigue syndrome associated with serologic evidence of reactivated, latent $\mathrm{EBV}$ infection. However, as the authors acknowledge, the demonstration of such an association does not prove that reactivation of EBV is the cause of the fatigue and associated symptoms seen in these patients. Indeed, the elevated EBV antibody titers may represent only an epiphenomenon; some other primary pathogenetic event (such as infection with another lymphotropic virus) could have caused the patients' illness and also reactivated a latent $E B V$ infection.

In this study, we attempted to assess the prevalence of a syndrome suggestive of the CEBV infection syndrome in an unselected population of patients seeking primary medical care. We found that a clinical syndrome suggestive of CEBV infection or chronic mononucleosis was present in a surprisingly high fraction $(21 \%)$ of patients aged 17 to 50 years, coming to our primary care practice; none of these patients were felt by their physicians to have evidence of other preexisting "organic" or psychiatric illnesses that could account for their symptoms. On the other hand, while these patients tended to have higher levels of antibody to EBV (particularly VCA-IgG and EA-Ab) than did age- and sex-matched control subjects who did not have a chronic fatigue syndrome, the differences between patients and control subjects almost never were statistically significant.

In contrast with several previous studies, we obtained control subjects from among patients (not laboratory technicians or employees) attending the same practice. The control subjects were matched for both age and sex, were asked specifically whether they had been experiencing chronic fatigue, and explicitly denied having chronic fatigue; the "normality" of the control subjects was not assumed. Finally, the antibody determinations in control subjects were performed blindly by the same technician who performed the determinations on patients.

It seems likely that our patients were less sick than patients in the several other recently reported studies. ${ }^{21-23}$ None of the 40 patients in our study had been fully disabled by his or her illness, in contrast with some patients in the previous studies, and the patients had relatively few days when they could not work. Also, the VCA-IgG and EA-Ab levels in our patients were lower than in these previous studies (although the fact that our serologic studies were performed in a different laboratory makes such comparisons hazardous). We expected any patients we detected with a syndrome suggestive of CEBV infection to be less sick than previously described patients, since we were seeing patients seeking primary care for any reason; we were not seeing patients referred for evaluation of chronic fatigue.

At the same time, the patients reported in this study had been experiencing considerable morbidity from their syndrome (Table 1), for a median duration of 16 months (range, six to 458 months). Sixty percent reported that the syndrome had caused substantial stress at home and at work. The majority stated that the fatigue became so severe that they were periodically bedridden; the associated myalgias and headaches became so severe at times that the patients had to stop all normal activities and rest. Twenty-five percent of the patients stated that they had sought help for the problem from multiple physicians, to no avail. 
Many of the symptoms associated with the CEBV infection syndromeparticularly the chronic fatigue, myalgias, and headache-are also manifestations of chronic depression and anxiety. Therefore, it is possible that some of these patients were suffering from a psychoneurosis, even though none of them were being treated for a psychoneurosis at the time that their chronic fatigue syndrome started. At the same time, depression and anxiety do not so easily explain the recurrent

\section{References}

1. Hallee TJ, Evans AS, Niederman JC, et al: Infectious mononucleosis at the U.S. Military Academy: A prospective study of a single class over four years. Yale J Biol Med 1974;47:182-195.

2. Evans AS: Epstein-Barr virus, in Evans AS (ed): Viral Infections of Humans: Epidemiology and Control. New York, Plenum Publishing Corp 1976, pp 9-33.

3. Aronson MD, Komaroff AL, Pass TM, et al Heterophil antibody in adults with sore throat: Frequency and clinical presentation. Ann Interm Med 1982;96:505-508.

4. Miller G, Niederman JC, Andrews L: Prolonged oropharyngeal excretion of Epstein-Barr virus after infectious mononucleosis. $N$ Engl $J \mathrm{Med}$ 1973;288:229-232.

5. Rochi G, de Felici A, Ragona G, et al: Quan titative evaluation of Epstein-Barr-virus-infected mononuclear peripheral blood leukocytes in infectious mononucleosis. $N$ Engl J Med 1977;296: 132-134.

6. Bar RS, DeLor CJ, Clausen KP, et al: Fatal infectious mononucleosis in a family. $N$ Engl $J \mathrm{Med}$ 1974;290:363-367.

7. Purtilo DT, Cassel CK, Yang JP, et al: X-linked recessive progressive combined variable immunodeficiency (Duncan's disease). Lancet 1975;1 935-941.

8. Purtilo DT, Sakamoto K, Saemundsen AK, et al Documentation of Epstein-Barr virus infection in immunodeficient patients with life-threatening lymphoproliferative diseases by clinical, virological and immunopathological studies. Cancer Res 1981; 41:4226-4236.

9. Robinson JE, Brown N, Andiman W, et al Diffuse polyclonal B-cell lymphoma during primary infection with Epstein-Barr virus. $N$ Engl J Med 1980;302:1293-1297.

10. Snydman DR, Rudders RA, Daoust $P$, et al Infectious mononucleosis in an adult progressing to fatal immunoblastic lymphoma. Ann Intern Med 1982;96:737-742.

11. Abo W, Takada K, Kamada M, et al: Evolution of infectious mononucleosis into Epstein-Barr virus carrying monoclonal malignant lymphoma. Lancet 1982;1:1272-1276.

12. Hanto DW, Frizzera G, Gajl-Peczalska KF et al: Epstein-Barr virus-induced B-cell lymphoma after renal transplantation: Acyclovir therapy and transition from polyclonal to monoclonal B-cel proliferation. $N$ Engl J Med 1982;306:913-918.

13. Hochberg FH, Miller G, Schooley RT, et al Central-nervous-system lymphoma related to Epstein-Barr virus. $N$ Engl J Med 1983;309:745-748. 14. Martin PJ, Shulman HM, Schubach WH, et al Fatal Epstein-Barr-virus-associated proliferation of donor B cells after treatment of acute graftversus-host disease with a murine anti-T-cell antibody. Ann Intern Med 1984;101:310-315. pharyngitis, adenopathy, paresthesias, arthralgias, or fevers reported by many patients.

The results of this study indicate that a chronic fatigue syndrome suggestive of a mild form of the CEBV infection syndrome may be surprisingly common in a primary care practice. However, our study offers no proof that EBV plays a causal role in the pathogenesis of this syndrome. Furthermore, our study emphasizes the difficulties of diagnosing this syndrome using currently avail-

15. Sullivan JL, Medveczky P, Forman SJ, et al: Epstein-Barr-virus induced lymphoproliferation: Implications for antiviral chemotherapy. $N$ Engl J Med 1984;311:1163-1167.

16. Shearer WT, Ritz J, Finegold MJ, et al: Epstein-Barr virus-associated B-cell proliferations of diverse clonal origins after bone marrow transplantation in a 12-year-old patient with severe combined immunodeficiency. $N$ Engl J Med 1985;312: 1151-1159.

17. Tobi M, Morag A, Ravid Z, et al: Prolonged atypical illness associated with serologic evidence of persistent Epstein-Barr virus infection. Lancet 1982;1:61-64

18. Ballow M, Seeley J, Purtilo DT, et al: Familia chronic mononucleosis. Ann Intern Med 1982;97: 821-825.

19. Edson CM, Cohen LK, Henle W, et al: An unusually high-titer human anti-Epstein Barr virus (EBV) serum and its use in the study of EBV. specific proteins synthesized in vitro and in vivo. $J$ Immunol 1983;130:919-924.

20. Hamblin TJ, Hussain J, Akbar AN, et al: Immunological reason for chronic ill health after infectious mononucleosis. Br Med J Clin Res 1983 287:85-88.

21. DuBois RE, Seeley JK, Brus I, et al: Chronic mononucleosis syndrome. South Med J 1984;77: 1376-1382.

22. Jones JF, Ray CG, Minnich LL, et al: Evidence for active Epstein-Barr virus infection in patients with persistent unexplained illnesses: Elevated anti-early antigen antibodies. Ann Intern $\mathrm{Med}$ 1985;102:1-7.

23. Straus SE, Tosato G, Armstrong G, et al: Persisting illness and fatigue in adults with evidence of Epstein-Barr virus infection. Ann Interm Med 1985;102:7-16.

24. Houghton LE, Jones EI: Persistent myalgia following sore throat. Lancet 1942;1:196-198.

25. Isaacs R: Chronic infectious mononucleosis. Blood 1948;3:858-861.

26. Kaufman RE: Recurrences in infectious mononucleosis. Am Prac 1950;1:673-676.

27. Paterson JK, Pinniger JL: A case of recurrent infectious mononucleosis. Br Med J Clin Res 1955 2:476.

28. Greenfield NS, Roessler R, Crosley AP: Ego strength and length of recovery from infectious mononucleosis. J Nerv Ment Dis 1959;129:125-128. 29. Bender CE: Recurrent mononucleosis. JAMA 1962;182:954-956.

30. Graves S: Recurrent infectious mononucleosis. $J$ Ky Med Assoc 1970;1:790-792.

31. Veltri RW, Sprinkle PM, McClung JE; Epstein-Barr virus associated with episodes of recurrent tonsillitis. Arch Otolaryngol Head Neck Surg 1975;101:552-556.

32. Cadie M, Nye FJ, Storey P: Anxiety and able serologic techniques, at least with patients seen in a general medicine primary care practice.

Minann, Inc, Glenview, IIl, and the Rowland Foundation, Inc, Cambridge, Mass, provided grant support for this study.

The authors would like to thank Steven Emond, Paul Mischel, Elaine Gebhardt, Sharon M. Baker, MT, and Dianne Willitts for their invaluable help in performing this study. Dr Sullivan is an Established Investigator of the American Heart Association. Dr Buchwald is a Henry J. Kaiser Family Foundation Fellow in General Internal Medicine.

depression after infectious mononucleosis. $\mathrm{Br}$ Psychiatry 1976;128:559-561.

33. Horwitz CA, Henle W, Henle G, et al: Clinical evaluation of patients with infectious mononucleosis and development of antibodies to the $\mathrm{R}$ component of the Epstein-Barr virus-induced early antigen complex. Am J Med 1975;58:330-338.

34. Smith H, Denman AM: A new manifestation of infection with Epstein-Barr virus. Br Med J Clin Res 1978;2:248.

35. Virelizier J, Lenoir G, Griscelli C: Persistent Epstein-Barr virus infection in a child with hypergammaglobulinaemia and immunoblastic proliferation associated with a selective defect in immune interferon secretion. Lancet 1978;2:231-234.

36. Chang RS, Maddock R: Recurrence of infectious mononucleosis. Lancet 1980;1:704.

37. Schooley RT, Carey RW, Miller G, et al: Chronic Epstein-Barr virus infection associated with fever and interstitial pneumonitis: Clinical and serologic features and response to antiviral chemotherapy. Ann Intern Med 1986;104:636-643.

38. Joncas JH, Ghibu F, Blagdon $M$, et al: A familial syndrome of susceptibility to chronic active Epstein-Barr virus infection. Can Med Assoc J 1984;130:280-285.

39. Alfieri C, Ghibu F, Joncas JH: Lytic, nontransforming Epstein-Barr virus (EBV) from a patient with chronic active EBV infection. Can Med Assoc J 1984;131:1249-1252.

40. Sumaya CV, Henle W, Henle G, et al: Seroepidemiologic study of Epstein-Barr virus infections in a rural community. $J$ Infect Dis 1975;131. 403-408.

41. Sumaya CV: Endogenous reactivation of $\mathrm{Ep}$ stein-Barr virus infections. $J$ Infect Dis 1977;135 374-379.

42. Lamy ME, Favart AM, Cornu E, et al: Study of Epstein Barr virus (EBV) antibodies: IgG and IgM anti-VCA, IgG anti-EA and Ig anti-EBNA obtained with an original microtiter technique: Serological criterions of primary and recurrent EBV infections and follow-up of infectious mononucleosis: Seroepidemiology of EBV in Belgium based on 5178 sera from patients. Acta Clin Belg 1982;37: 281-298

43. Henle W, Henle G, Horwitz CA: Infectious mononucleosis and Epstein-Barr virus-associated malignancies, in Lennette EH, Schmidt NJ (eds): Diagnostic Procedures for Viral, Rickettsial and Chlamydial Infections, ed 5. New York, American Public Health Association, 1979, pp 441-470.

44. Reedman BM, Klein G: Cellular localization of an Epstein-Barr virus (EBV)-associated complement-fixing agent in producer and non-producer lymphoblastoid cell lines. Int $J$ Cancer 1973;11: 499-520. 